\title{
SYNTHESIS OF HAP-CHITOSAN-PVA COMPOSITE AS INJECTABLE BONE SUBSTITUTE MATERIAL
}

\author{
Firnanelty ${ }^{1}$, S. Sugiarti ${ }^{1, *}$ and Charlena ${ }^{1}$ \\ ${ }^{1}$ Department of Chemistry, Bogor Agricultural University, Bogor, West Java, 16680, Indonesia \\ *E-mail : sri.sw07@gmail.com
}

ABSTRACT

The main objective of this study is to synthesize a composite of hydroxyapatite (HAp)-chitosan-polyvinyl alcohol (PVA) and to evaluate its uses as bone filler. An injectable bone substitute (IBS) material is a suspension of bone filler which applied by injection to fill the gaps caused by osteoporosis. A hydroxyapatite used as the composite's component was synthesized from Tutut shell. The composite was made by mixing hydroxyapatite, chitosan and PVA to homogeneous followed by irradiation with gamma rays at $20 \mathrm{kGy}$. The composite was characterized by FTIR analysis, XRD, SEM, viscosity test, and cytotoxicity assay. The FTIR analysis showed the bond formation between hydroxyapatite and chitosan, which later formed cross linkages by the addition of PVA. The viscosity of the composite was 36dPa. The cytotoxicity assay (MTT assay) showed that the suspension is not toxic because the cell viability value was obtained at more than $50 \%$. As a conclusion, the composite of HAp from tutut shell-chitosan-PVA is suitable to be used as an injectable bone substitute.

Keywords: Hydroxyapatite, Injectable bone substitute, Osteoporosis, Tutut shell

(C) RASĀYAN. All rights reserved

\section{INTRODUCTION}

Bone filler is a suspension applied by injection to fill in the gaps caused by osteoporotic. This bone filler is also called an Injectable Bone Substitute (IBS). The advantage of using injectable system to prevent the loss of bone density, is that it can be formed according to the shape of the bone cavity, and it is polymerized in situ after being injected. Injectable materials are also sterile and ready to use ${ }^{1}$. To be used as IBS, a material should be osteoconductive and have a good mechanical strength $^{2}$.

One material that has osteoconductive property is hydroxyapatite. Hydroxyapatite (HAp) is a group of minerals apatite compound with chemical formula of $\mathrm{Ca}_{10}\left(\mathrm{PO}_{4}\right)_{6}(\mathrm{OH})_{2}$. HAp is a bioceramics that are frequently used as an element of the main in anorganic constituent of bones. Approximately $65 \%$ of bone mineral is hydroxyapatite ${ }^{3}$. Other properties of HAp are bioactive, biocompatible, non-toxic and nonimmunogenic ${ }^{4}$. However, HAp has some weakness as it is fragile, brittle, low resistance, and has a very slow resoption rate. When used alone, hydroxyapatite does not have a mechanical strength and is not resistant to pressure. Manipulation is needed to produce an ideal bone graft. A common strategy is by composited HAp with other materials such as chitosan to address its nature fragility. Its biocompatible, low toxicity, and anti-bacterial properties ${ }^{5}$ makes chitosan eligible for use as a bone substitute. The addition of chitosan causes a decrease of degradation properties and bond strength of bones ${ }^{6}$.

Polyvinyl alcohol (PVA), which has the mechanical characteristics and good biocompatibility can be used to enhance the performance of a composite ${ }^{7}$. PVA is widely used to replace a damaged body tissue because it possesses a physic-chemical property, particularly it is an excellent bio-tribiological due to its slick surface, resistant to friction and wear ${ }^{8}$. Furthermore, PVA has good biocompatibility ${ }^{9}$. In composite, PVA is also acting as cross-linking agent. Composites of hydroxyapatite-chitosan-PVA is suitable to be used as a bone substitute material for tissue engineering applications in the form of IBS, and in the presence of hydroxypropylmethyl cellulose (HPMC) as a suspending agent ${ }^{10}$. 
This conducted study is not only an attempt to correct the flaws on the nature of HAp, but also to select the most economical starting material in the manufacture of calcium phosphate. Tutut shell is an abundant waste and has not been used commercially. This waste is rich in various minerals including calcium ${ }^{11}$. Tutut shell contains mostly calcium carbonate with calcium content about $64.73 \%{ }^{12}$.

Synthesis of hydroxyapatite and the composites are done with wet precipitation method. To fit its purpose to be used in a human body, the composites received a high-intensity gamma irradiation to kill harmful organisms and simultaneously sterilizes the material. Visually, a composite which underwent irradiation showed a thick paste and a homogeneous gel consistency ${ }^{13}$. In this research, HAp synthesized from Tutut composited with chitosan and PVA to be used as IBS material. The resulting composite can be used in a variety of clinical purposes in the field periodontal, orthopedic and plastic surgery and has met some of the qualities required in lieu of bone (bone substitute) corresponding in vitro test result, physical and chemical $^{14}$.

\section{General Procedures}

\section{EXPERIMENITAL}

Cleaned shells of Tutut were boiled for 1 hour, the sundried, grounded, and shieved to give a 100 mesh of powder. The $\mathrm{Ca}$ level of the powder was determined before undergo calcinations process to give $\mathrm{CaO}$ compound. $\mathrm{Ca}(\mathrm{OH})_{2}$ was obtained by allowing the $\mathrm{CaO}$ to interact with air (hydrated) for one week period $^{15}$. Hydroxyapatite was synthesized through wet precipitation method from $\mathrm{Ca}(\mathrm{OH})_{2} 0,5 \mathrm{M}$ by a reaction with $\left(\mathrm{NH}_{4}\right)_{2}$. $\mathrm{HPO}_{4} 0,3 \mathrm{M}$ according to the following reaction:

$$
10 \mathrm{Ca}(\mathrm{OH})_{2}+6\left(\mathrm{NH}_{4}\right)_{2} \cdot \mathrm{HPO}_{4} \longrightarrow \mathrm{Ca}_{10}\left(\mathrm{PO}_{4}\right)_{6}(\mathrm{OH})_{2}+6 \mathrm{H}_{2} \mathrm{O}+12 \mathrm{NH}_{4} \mathrm{OH}
$$

Composite of HAp-chitosan-PVA was synthesized trough sol method. $0.5 \%$ solution of chitosan in $3 \%$ of acetic acid was mixed with $5 \%$ which previously dissolved in water. Solution of hydroxyapatite is the added into the mixture, followed by a solution of HMPC $2 \%$. The mixture then stirred at room temperature for 6 hours to give a white suspension. The composite the irradiated with a dose of 20 kGy. The synthesized composites were analyzed using XRD, FTIR and SEM. Since the composites are addressed as injectable material, a suspension made from the composites were tested for its viscosity value. The viscosity of the suspension was measured using Viscotester TV-10.

\section{Cytotoxicity test of the composite}

Cytotoxicity of the composite was tested by the MTT (3-(4,5-dimetiltiazol-2-yl)2,5-difeniltetrazolium bromide) performed on CPAE cells. CPAE cells were grown in DMEM medium. Cells used inoculated plates comprising 96 wells by the number of media grower $100 \mathrm{~mL} /$ well containing 2200 cells $/$ well. A total of $100 \mathrm{~mL}$ sample with a sequence specific concentration was added to the inoculants, then incubated for 48 hours in a $5 \% \mathrm{CO}_{2}$ incubator at $37{ }^{\circ} \mathrm{C}$. Further into each well added $10 \mathrm{~mL}$ of MTT and incubated back for 4 hours in a $5 \% \mathrm{CO}_{2}$ incubator at $37{ }^{\circ} \mathrm{C}$. Living cells that react with MTT to form formazan become blue. Formazan formed was dissolved in $96 \%$ ethanol. Uptake is read by a spectrophotometer ELISA microplate reader at $\lambda 595 \mathrm{~nm}$.

\section{RESULTS AND DISCUSSION}

Shells of Tutut, Figure-1, is a source of calcium, in the form CaCO3. XRD analysis of Tutut Shell powder showed peaks for aragonite $\mathrm{CaCO}_{3}$ as the main component, as shown by Figure-2a.

The transformation of $\mathrm{CaCO}_{3}$ to $\mathrm{CaO}$ was done by calcinations at temperature between 1000 to $1200{ }^{\circ} \mathrm{C}$ for 3 hours. This high temperature is chosen to prevent the high formation of $\mathrm{CO}_{2}$. The obtained $\mathrm{CaO}$ compound was converted into $\mathrm{Ca}(\mathrm{OH}) 2$ by direct contact with air, following the equation:

$$
2 \mathrm{CaO}_{9(\mathrm{~s})}+2 \mathrm{H}_{2} \mathrm{O}_{(\mathrm{g})} \longrightarrow 2 \mathrm{Ca}(\mathrm{OH})_{2(\mathrm{~s})}
$$

The XRD pattern of Tutut shell after calcinations indicates that the powder mainly consisted of portlandite $\left(\mathrm{Ca}(\mathrm{OH})_{2}\right)$ as shown by the presence of peaks at $2 \theta\left(^{\circ}\right)$ of $18.18,28.68,34.30,47.40,50.92$, 54.16, 62.62, 64.16, 67.46 (Figure-2b). 
The Calcium content of Tutut shell powder was $55.37 \%$ which has lower than the results reported who found the value to be $64.73 \%^{16}$. However, this calcium content is higher than that of rice fields nail shell which was found to be $52 \%{ }^{17}$. This high content of calcium showed that Tutut shell can be used as precursor in the synthesis of HAp.

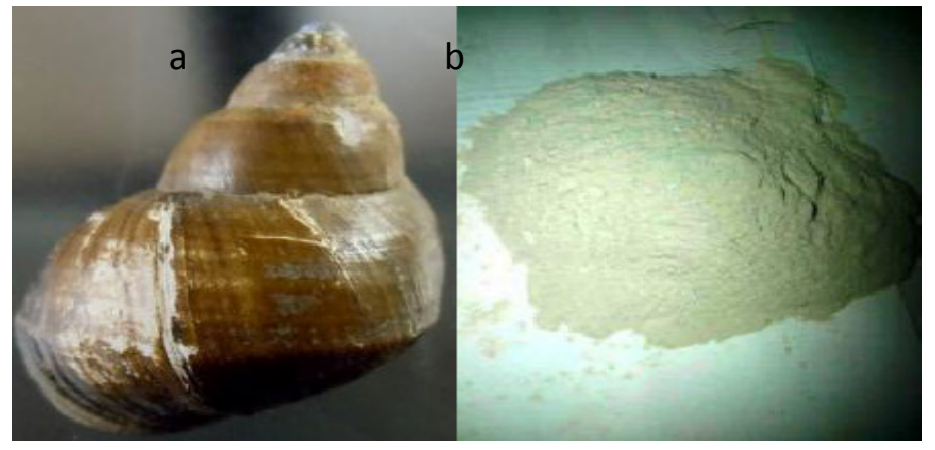

Fig.-1: Shells of Tutut (Bellamya javanica) (a) Dry, (b) Powder

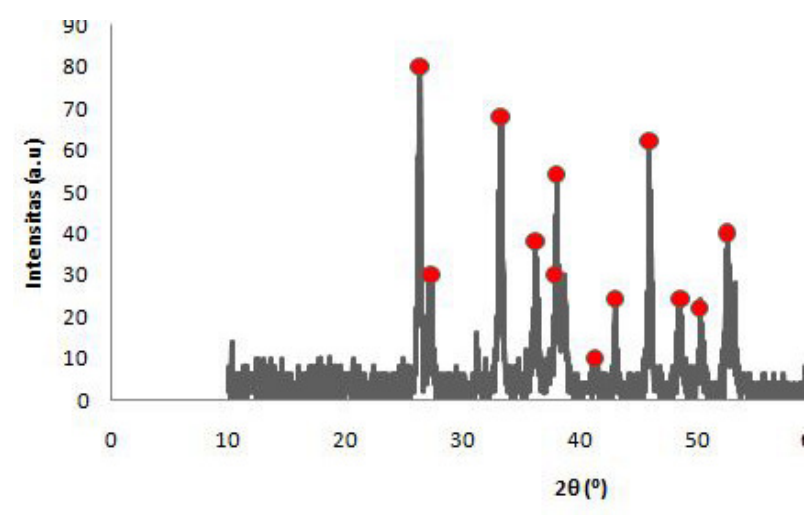

Fig.-2a: Diffractogram x-ray Tutut shell powder

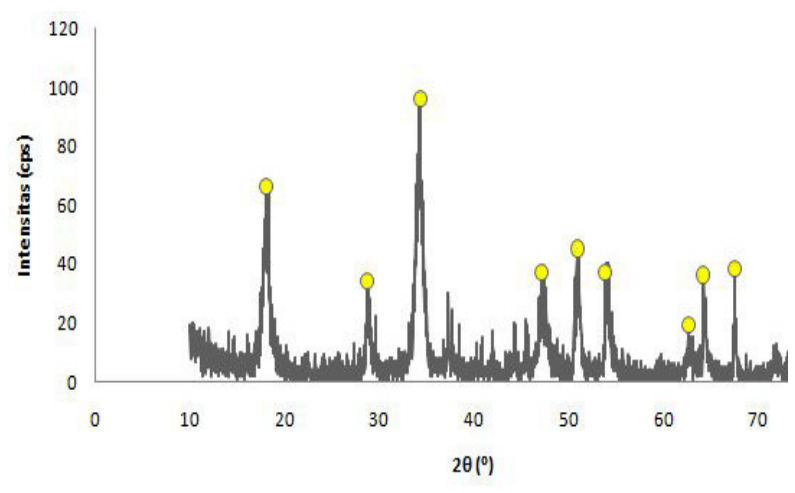

Fig.-2b: Diffractogram x-ray of calcined Tutut shell powder

Hydroxyapatite (HAp) was synthesized using wet precipitation method. This method does not need organic solvent and the yield is usually higher ${ }^{18} \cdot \mathrm{Ca}(\mathrm{OH})_{2}$ is used as the source of calcium, while solution of $\left(\mathrm{NH}_{4}\right)_{2} \mathrm{HPO}_{4}$ is used as the source of phosphate. In the synthesis process it is necessary to monitor and adjust the $\mathrm{pH}$ level of the solution. If the $\mathrm{pH}$ of solution is less than 10 or more than 10 . It will cause the formation of calcium monophosphate and calcium dehydrated, two compounds that soluble in water ${ }^{19}$. Therefore, this process must be carried out at $\mathrm{pH} 10$ which is the optimum $\mathrm{pH}$ for the formation of $\mathrm{HAp}^{20}$.the formation of HAp was indicated by the presence of peaks at $2 \theta\left(^{\circ}\right)$ angle of $31.98,32.96$, and 33.08 (Figure-3a).

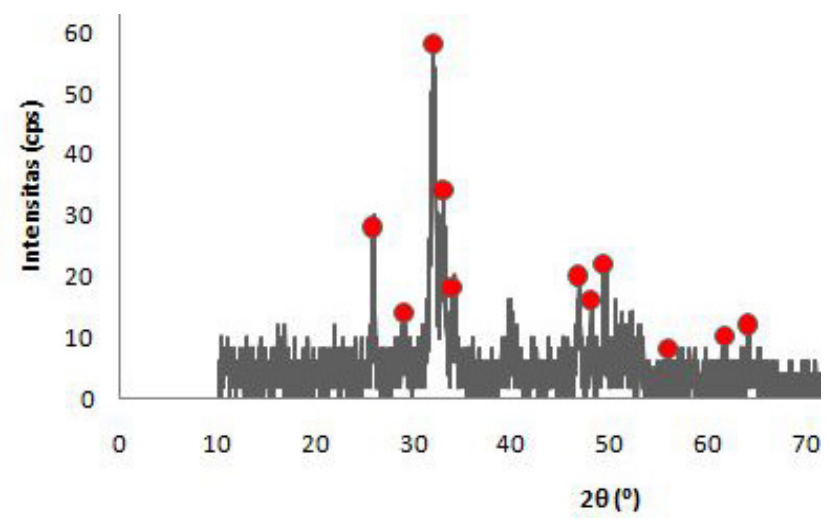

Fig.-3a: Diffractogram of HAp from Tutut shell

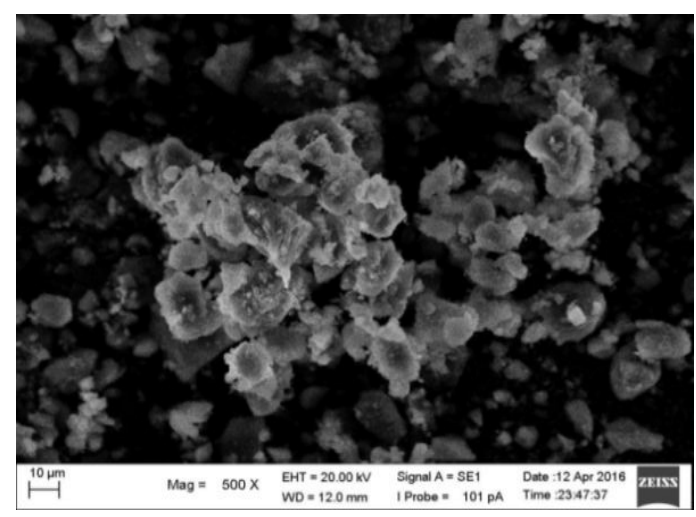

Fig.-3b: Morphology of synthesized of HAp 
Morphological observation using SEM showed the formation of an agglomeration (Figure-3b) and makes it difficult to determine the crystal size of the synthesized HAp, a similar result with synthesized HAp that the size of HAp crystal grains was reported to be around 150-300 $\mathrm{nm}^{21,22}$. The SEM also showed that the single particle of HAp crystals tend to form a round shape.

FTIR spectrum also confirmed the formation of HAp by the presence of absorption peak at 604 and 565 $\mathrm{cm}^{-1}$ showing the bending mode of phosphate $\left(\mathrm{PO}_{4}{ }^{3-}\right)$ cluster, and the absorption at $1033 \mathrm{~cm}^{-1}$ showing the stretching mode of phosphate group (Figure-4). The absorption peak at $1421 \mathrm{~cm}^{-1}$ is an indication of a carbonate groups $\left(\mathrm{CO}_{3}{ }^{2-}\right)$. The hydroxyl group $(\mathrm{OH})$ of HAp appeared at $3431 \mathrm{~cm}^{-1}$. The FTIR results showed that the phosphate groups are the dominant compounds presence of a very small amount of calcium carbonate ${ }^{23}$.

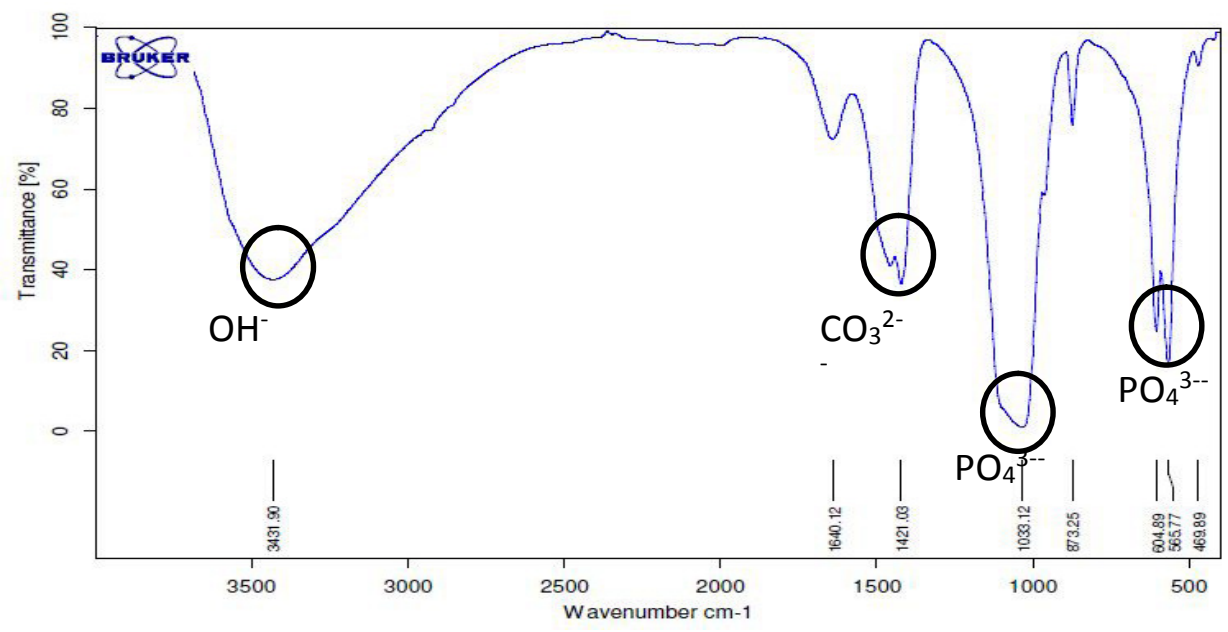

Fig.-4: FTIR spectrum of synthesized hydroxyapatite

The synthesized Hap was mixed physically with chitosan and PVA to give a composite that later used as IBS material. Gamma rays were used to sterilize and to jellify the compsoite, at a dose of $20 \mathrm{kGy}$ based on the Association for theAdvancement of Medical Instrumentation (AAMI) TIR33: 2005 which states that the dose for sterilization is in range of 15 to $35 \mathrm{kGy}$. Gamma irradiation is used for the sterilization of materials to be used in the health field because it left no radioactive residue. Visually, after the irradiation, the IBS sample showed a colorless and homogeneous clear gel.

Interaction between materials used in the formation of composite was observed using FTIR, and the results is given on Figure-5. The polyvinyl alcohol (PVA) is showed by the absorption at $3438 \mathrm{~cm}^{-1}(\mathrm{OH}$ stretch vibration), $2924 \mathrm{~cm}^{-1}\left(\mathrm{CH}\right.$ stretch vibration/ $\left.\mathrm{CH}_{2}\right), 1701 \mathrm{~cm}^{-1}$ (strain vibration $\left.-\mathrm{C}=\mathrm{O}\right), 1381 \mathrm{~cm}^{-1}$ (strain $-\mathrm{CH}$ vibration), $1055 \mathrm{~cm}^{-1}$ (vibration $-\mathrm{C}-\mathrm{C}$-). In addition, the hydrogen bond on PVA (HOH bond) was observed at $1649 \mathrm{~cm}^{-1}$. Meanwhile, the chitosan gave the absorption peaks at $3730 \mathrm{~cm}^{-1}$ (strain vibration $\mathrm{H}-\mathrm{NH}$ ), and at $1654 \mathrm{~cm}^{-1}$ for the functional group of amide I. A sharp peak at $1421 \mathrm{~cm}^{-1}$ indicated the mode changes of $\mathrm{CH}_{3}$ symmetrical shape. Chitosan also showed absorption peaks at 3432 $\mathrm{cm}^{-1}$ (OH stretch vibration). The three materials was interacted by a hydrogen bonding which was showed by the presence of the absorption peaks at $3000-3500 \mathrm{~cm}^{-1}$, an indication of a merge vibrations of the $\mathrm{OH}$ of hydroxyapatite, chitosan and PVA. In the FTIR spectrum composite, the absorption peaks of each material are still observable bt with a decrease in intensity, as shown by the peak at $2874 \mathrm{~cm}^{-1}$ (vibration $\mathrm{CH}$ aliphatic of chitosan). The absorption peaks of Tutut shell still appear at $3431 \mathrm{~cm}^{-1}(\mathrm{OH}$ stretch vibration), $1640 \mathrm{~cm}^{-1}$ (H-OH bending vibration), and at $1033 \mathrm{~cm}^{-1}, 604 \mathrm{~cm}^{-1}$ and $565 \mathrm{~cm}^{-1}$ for the phosphate group. A broadening peak around $300-3500 \mathrm{~cm}^{-1}$ is due to the interaction between the constituent elements of the composite, such as hydrogen bonding between chitosan-hydroxyapatite. The $\mathrm{OH}$ and $\mathrm{NH}_{2}$ groups of chitosan bind with the $-\mathrm{OH}$ group of hydroxyapatite ${ }^{24}$.

Figure-6a showed the XRD pattern for the composite, and showed that the composite consisted of mostly amorphous materials. The major content of the composite is the semicrystalline PVA, and appeared as a 
broad peak at $2 \theta$ angle of $19.84^{\circ}$. The hydroxyapatite peaks can be seen at $2 \theta\left(^{\circ}\right) 31.98,32.96,33.08$, while the amorphous chitosan appeared at $20.42^{\circ}$. Interaction between chitosan and PVA caused a disappearance of peak at $19.84^{\circ}$ for PVA and at $21.42^{\circ}$ for chitosan to give a single peak $19.57^{\circ}$. The XRD pattern is also tell that the mixture of the three elements do not form a new compound, as no new diffraction peaks appeared in the composite diffration pattern.

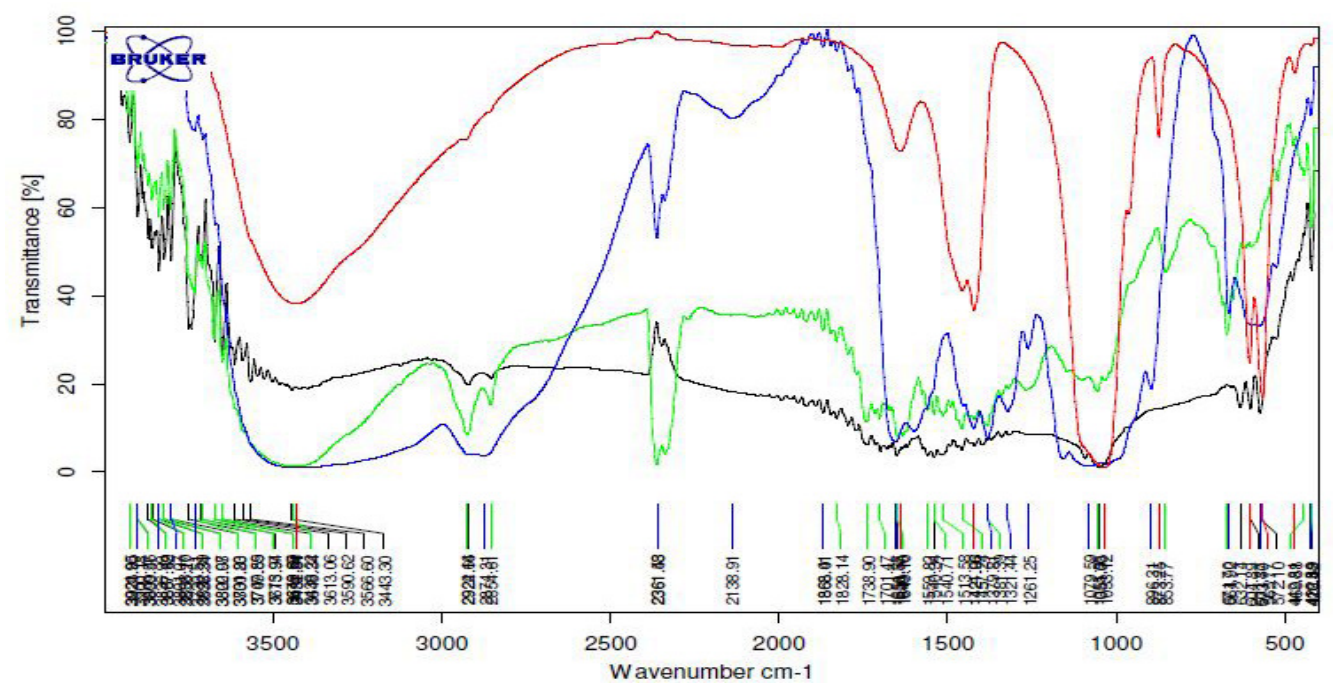

Fig.-5: Spectrum of FTIR PVA $(-)$, chitosan ( - ), hydroxyapatite ( $\square$ ), and composite HAp-Chitosan-PVA (

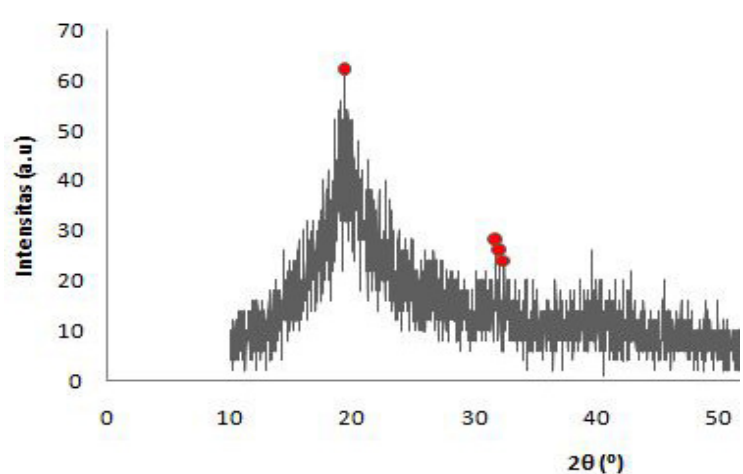

Fig.-6a: Diffractogram X-ray of composite HApchitosan-PVA

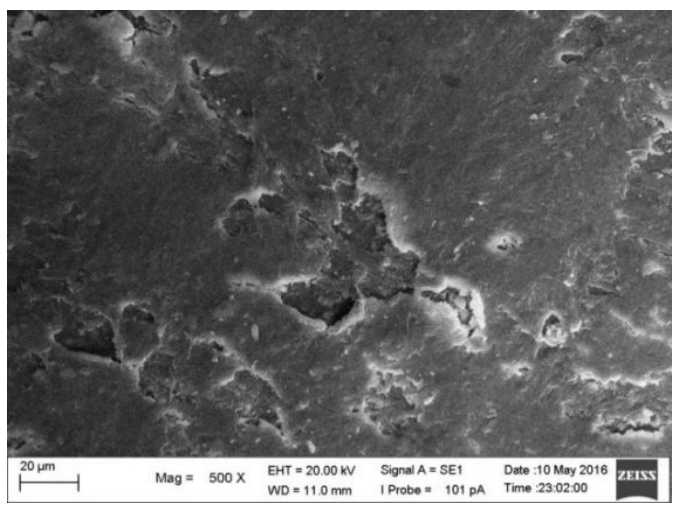

Fig.-6b: Morphology of composite HAp-chitosanPVA

The morphology of the IBS composite is shown in Figure 6b. The surface of the composite is seen to be porous, and coated by a membrane of microporous hydroxyapatite. This porous membrane enables the circulation of bodily fluids and blood ${ }^{25}$. The composite showed a viscosity level $36 \mathrm{dPa}$.s. The viscocity values possessed by this composite is very close to the standard values of injectable bone substitute which is $40 \mathrm{dPa} \cdot \mathrm{s}^{26}$. Qualitatively, the suspension made from the composite can be applied as an injectable bone substitute.

The citotoxicity test of the composite was done in vitro using an endhotelial culture media. This test aims to determine cell viability in the event of direct contact with the sample. Endhothelial cells was chosen because they are the main cells involved in blood vessel formation. Hydroxyapatite is known to increase the poliferation of endothelial cells, a precess that is required for the formation of new blood vessels 
(angiogenesis) which is crucial in the repair process of damaged tissue, tissue growth, and thehealing process $^{27}$. The concentration (\%) of the compposite used in the MTT test was 100, 75, 50, 25, and 12.5. The test results indicated that the limit of the composite concentration consider to be safe or not toxic is $12.5 \%$, with percentage of inhibition of $13.13 \%$, which means that more than $50 \%$ of the CPAE cells remian alive. If percent inhibition exceeds $50 \%$, the composite classified as toxic material ${ }^{28}$. Cytotoxicity test results can be seen in Figure-7, as more white lines of live CPAE cells can be seen on Figure-7e, in the presence of the composite test solution.

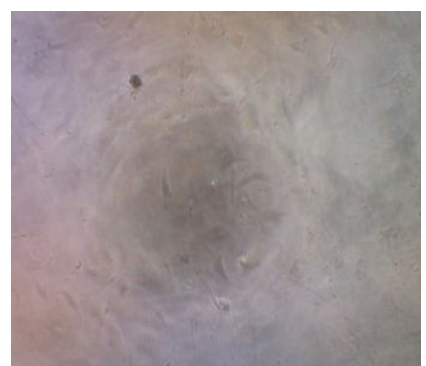

(a)

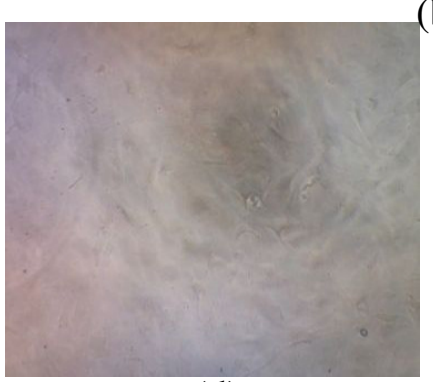

(d)

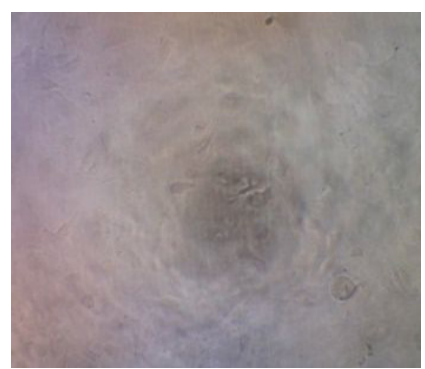

(b)

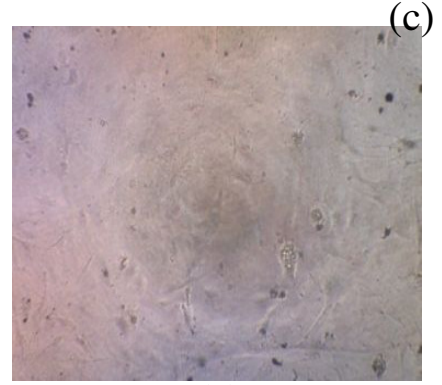

(e)

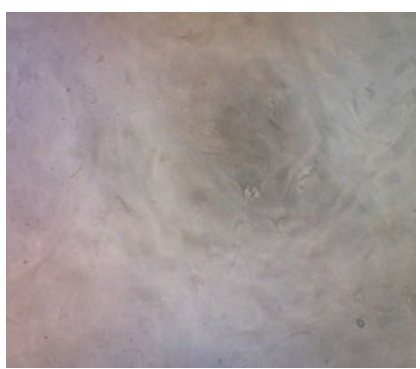

(c)

Fig.-7: The MTT test of the composite against CPAE cells with a series of concentration (a) $100 \%$ (b) $75 \%$ (c) $50 \%$ (d) $25 \%$ (e) $12.5 \%$

\section{CONCLUSION}

A hydroxyapatite has been succesfully synthesized from Tutut shell using wet precipitation method. The composite made from the Tutut shell Hap-chitosan-PVA can be used as injectable bone substitute. The IBS made from the composites has viscocity value of $36 \mathrm{dPa} . \mathrm{s}$, fairly close to the standard value for injectabke bone substitute material. The results of cytotoxicity assay (MTT assay) indicates the composite is not toxiv as the value of the cell viability is more than $50 \%$.

\section{REFERENCES}

1. Y. Warastuti and B. Abbas, A Scientific Journal for the Applications of Isotope and Radiations, $74(2011)$

2. W. Pierre, P. Layrolle, PL. Clergeau, B. Enckel, P. Pilet, Y. Amouriq, G. Daculsi, and B. Giumelli, Biomaterials. 28, 3295(2007)

3. R. Petit, European Journal of Orthopedic surgery \& amp; Traumatology, 9, 71(1999)

4. K.A .Nayak, Inernational Journal of Chemical Technology Research, 2(2), 903(2010)

5. P. Sugita, T. Wukirsari, A. Sjahriza, and D. Wahyono, Chitosan of Sources Biomaterials for Future, Bogor, p 148 (2009)

6. K.R. Mohamed, Z.M. El-Rashidy, and A.A. Salama, Journal Ceramic International, 37, $3265(2011)$

7. Ma'ruf, W. Siswomihardjo, M.H.N.E.Soesatyo, and A.E.Tontowi, Journal of Teknosains, 3, $1(2013)$ 
RASĀYAN J. Chem.

Vol. 10 | No. 2 |570 - 576 | April - June | 2017

8. A. N. Suciu, T. Iwatsubo, and M. Matsuda, The Japan Society of Mechanical Engineers 47(1), 199(2004)

9. Y. S. Pan, D. S. Xiong, and R. Y. Ma, Wear. 262,1021(2007)

10. P. Weiss, O. Gauthier, J. M. Bouler, G. Grimandi, and G. Daculsi, Equipe INSERM Materiaux, 1, 1(2007)

11. R. L. .Baby, I.. Hasan, K. A. .Kabir, and M. N. .Naser. Journal of Scientific Research. 2(2), 390(2010)

12. L. Herawaty, Thesis, Department Chemistry, Bogor Agricultural University, Bogor, Indonesia (2014)

13. M. Azami, S. Tavakol, A. Samadikuchaksaraei, M. S. Hashjin, N. Baheiraei, M. Kamali, and M. R. Nourani, In Vitro and In Vivo of Biomaterials Science (2012)

14. C. Soído, M. C. Vasconcellos, A. G. Diniz, and J. Pinheiro, Brazilian archives of Bio Tech 52(1), 93(2009)

15. Winata, Minithesis, Department of Chmeistry, Bogor Agricultural, Bogor, Indonesia

16. G. M. Cunniffe, F. J. O'Brian, S. Partap, T. J. Levingstone, K. T. Stanton, and G. R .Dickson, Journal Biomedical Material Research, 95 (4), 1142(2010)

17. A. Afshar, M. Ghorbani, N. Ehsani, M. R. Saeri, and C. C. Sorrell, Materials and design. 24, 197(2003)

18. K. Dahlan, F. Prasetyanti, and Y. W. Sari, Biophysics journal, 5(2), 71(2009)

19. H. Elsami, M. Solati-Hashjir, M. Tahriri, and F. Bakhshi, Materials Science-Poland, 28 (2010)

20. S. U. Maheshwari, V. K. Samuel, and N. Nagiah, Ceramics International, 40, 8469(2014)

21. D. Darwis and Y. Warastuti , Scientific Journal of Isotope and Radiation Applications, 4(2), 143(2008)

22. L. Pighinelli and Kucharska, Carbohydrate Polymers, 93, 256(2013).

23. Teng and Shu-hua, Journal Biomedical Material Reseacrch, 88A, 569(2008)

24. A. Putra, A. Ifada, A. Rahmah, F. Rahmawati, F. Qulub, and D. Hikmawati, I n Proceedings of the Seminar National Applied Physics, Surabaya, East Java (2014)

25. M. Rucker, M. W. Laschke, D. Junker, C. Carvalho, A. Schramm, R. Mulhaupt, N. C. Gellrich, and M. D. Menger. Biomaterials, 27, 5027(2006)

26. T. Matsuura, R. Hosokawa, K. Okamoto, T. Kimoto, and Y. Akagawa. Biomaterials, 21(11), 1121(2000)

[RJC-1465/2016] 